\title{
HUKUMAN TERHADAP KORUPTOR DALAM PERSPEKTIF HUKUM ISLAM
}

\section{PUNISHMENT FOR CORRUPTOR IN THE PERSPECTIVE OF ISLAMIC LAW}

\author{
Saenal Wahid \\ Sekolah Tinggi Ilmu Islam dan Bahasa Arab (STIBA) Makassar \\ email: al_wahid88@yahoo.co.id
}

\begin{tabular}{|c|c|}
\hline Keywords : & ABSTRACT \\
\hline $\begin{array}{l}\text { punishment, corruption, } \\
\text { criminal, Islamic law } \\
\text { perspective }\end{array}$ & $\begin{array}{l}\text { The purpose of this study was to know the punishment for corruptors } \\
\text { in the perspective of Islamic law. The type of research was } \\
\text { qualitative research based on library research. The results showed } \\
\text { that the forms of violation of the law of corruption in Indonesia in } \\
\text { the perspective of Islamic law can be in the form of ghulul(treason), } \\
\text { al-ghasy (fraud), and risywah (bribery), al-hirabah (exploitation), } \\
\text { and al-ghasab (use of the rights of others without permission). The } \\
\text { elements of criminal acts of corruption in the perspective of Islamic } \\
\text { Criminal Law are the existence of texts that prohibit it, then having } \\
\text { committed acts that have violated the texts, for example committing } \\
\text { khiyanah/ghulul, al-ghasy (fraud), risywah (bribery), al-hirabah } \\
\text { (deprivation), al-ghasab (use of other people's rights without } \\
\text { permission), and finally the perpetrators are people who can be } \\
\text { charged with law. The punishment for corruptors in the context of } \\
\text { Islamic Criminal Law can be in the form of takzir, moral sanctions, } \\
\text { social sanctions and sanctions of the afterlife. }\end{array}$ \\
\hline \multirow{2}{*}{$\begin{array}{l}\text { Kata kunci : } \\
\text { hukuman, koruptor, pidana, } \\
\text { perspektif hukum islam }\end{array}$} & ABSTRAK \\
\hline & $\begin{array}{l}\text { Penelitian ini disusun untuk mengetahui hukuman terhadap koruptor } \\
\text { Dalam Perspektif Hukum Islam. Jenis penelitian ini adalah jenis } \\
\text { penelitian kualitatif yang didasarkan pada penelitian library } \\
\text { research. Hasil penelitian menunjukkan bahwa bentuk-bentuk } \\
\text { pelanggaran hukum korupsi di Indonesia dalam perspektif hukum } \\
\text { Islam adalah bisa berupa ghulul (pengkhianatan), al-ghasy } \\
\text { (penipuan), dan risywah (suap), al-hirabah (perampasan), dan al- } \\
\text { ghasab (penggunaan hak orang lain tanpa izin). Adapun unsur-unsur } \\
\text { tindak pidana korupsi dalam perspektif Hukum Pidana Islam adalah } \\
\text { adanya nas yang melarangnya, kemudian telah melakukan perbuatan } \\
\text { yang telah menyalahi nas-nas, dan pelakunya adalah orang yang } \\
\text { sudah dapat dibebankan hukum. Hukuman bagi pelaku tindak pidana } \\
\text { korupsi dalam konteks Hukum Pidana Islam dapat berupa takzir, } \\
\text { sanksi moral, sanksi sosial dan sanksi akhirat. }\end{array}$ \\
\hline
\end{tabular}

Diterima: 27 Mei 2021; Direvisi: 12 Agustus 2021; Disetujui: 12 Agustus 2021; Tersedia online: 20 Agustus 2021

How to cite: Saenal Wahid, "Hukuman Terhadap Koruptor dalam Perspektif Hukum Islam", BUSTANUL FUQAHA: Jurnal Bidang Hukum Islam 2, No. 2 (2021): 181-193. doi:10.36701/bustanul. v2i2.336. 


\section{PENDAHULUAN}

Salah satu problem global yang paling memprihatinkan saat ini adalah persoalan korupsi ${ }^{1}$. Hal ini dikarenakan korupsi merupakan persoalan yang menjadi faktor perusak tatanan birokrasi serta menyebabkan munculnya ketidakadilan di masyarakat ${ }^{2}$. Bentuk nyata tingkah laku korupsi bisa berwujud penggelapan, penyuapan, penyogokan, manipulasi data administrasi keuangan dan perbuatan sejenis lainnya ${ }^{3}$. Dari pandangan tersebut maka dapat disimpulkan bahwa tindakan korupsi merupakan perbuatan melawan hukum, berupa penyimpangan kekuasaan dan jabatan, privatisasi fasilitas, penyuapan atau penyogokan, penipuan.

Menurut Soejono, terdapat banyak faktor yang menyebabkan terjadinya tindak pidana korupsi. Salah satu faktor tersebut adalah adanya perkembangan dan perbuatan pembangunan khususnya di bidang ekonomi dan keuangan yang telah berjalan dengan cepat, serta banyak menimbulkan berbagai perubahan dan peningkatan kesejahteraan. ${ }^{4}$

Berbagai upaya telah dilakukan guna mencegah dan menghilangkan praktek korupsi di Indonesia. Namun realitasnya, korupsi tetap saja menjamur bahkan sudah dianggap sebagai bagian dari "budaya" bangsa. Bahkan di era otonomi daerah sekarang ini, korupsi sudah menyebar di berbagai daerah lokal. Langkah solusi yang ditawarkan untuk menghilangkan budaya korupsi di masyarakat salah satunya adalah dengan cara menghukum para penjahat atau pelaku dengan hukuman yang seberat-beratnya ${ }^{5}$.

Islam merupakan agama yang menjunjung tinggi aspek keadilan dan menentang perbuatan-perbuatan yang merugikan masyarakat. Menurut Makhrus Munajat, perbuatan dianggap sebagai tindak kejahatan karena merugikan tatanan kemasyarakatan, kepercayaan-kepercayaan, harta benda, nama baik, kehormatan, jiwa dan lain sebagainya, yang kesemuanya itu menurut hukum syara' harus dipelihara dan dihormati serta dilindungi ${ }^{6}$. Dengan demikian, suatu sanksi diterapkan kepada pelanggar syara' dengan tujuan agar seseorang tidak mudah berbuat kejahatan. Dalam hal ini, korupsi merupakan perbuatan yang sangat merugikan baik kepada individu, masyarakat, dan negara.

Berdasarkan uraian latar belakang di atas, penelitian ini dilakukan dengan tujuan untuk mengetahui bagaimana pandangan Islam tentang kejahatan korupsi dan hukum Islam terhadap pelaku tindak pidana korupsi. Untuk mengkajinya secara komperehensif, penelitian ini menggunakan metode kepustakaan (library research) yaitu serangkaian

\footnotetext{
${ }^{1}$ John M Echols and Hassan Shadily, Kamus Inggris Indonesia, (Jakarta: Gramedia Pustaka Utama 2003). h. 145

2 Pope. Jeremy, Strategi Memberantas Korupsi: Elemen Sistem Integritas Nasional (Alih Bahasa Masri Maris) (Jakarta: Transparency Internasional Indonesia, 2008). h. 9.

${ }^{3}$ Ibid., h 15-17.

${ }^{4}$ Soejono, Kejahatan Dan Penegakan Hukum Di Indonesia (Jakarta: Rineka Cipta, 1996). h. 17.

5 Taufik Rinaldi dkk, Memerangi Korupsi di Indonesia yang Terdesentralisasi, Studi Kasus Penanganan Korupsi Pemerintah Daerah, (t.p: Justice the Poor Project, 2007), h. 5-6.

${ }^{6}$ Makhrus Munajat, Dekonstruksi Hukum Pidana Islam (Yogyakarta: Logung Pustaka, 2004). h. 5.
} 
kegiatan yang berkenan dengan metode pengumpulan data pustaka, membaca dan mencatat serta mengolah bahan penelitian.

Adapun penelitian terdahulu yang bersinggungan dengan tulisan ini di antaranya adalah hasil penelitian yang berjudul "Hukuman bagi Pelaku Korupsi: Studi Komparatif Hukum Positif dan Hukum Pidana Islam", yang membahas tentang hukuman bagi pelaku tindak pidana korupsi ditilik dari konstruksi hukum positif dan hukum pidana. Berbeda dengan penelitian sebelumnya, tulisan ini membahas tentang pandangan islam tentang kejahatan korupsi, dan pandangan hukum islam tentang pelaku tindak pidana korupsi. ${ }^{7}$

\section{PEMBAHASAN}

\section{Pandangan Islam Tentang Kejahatan Korupsi}

Penegakan hukum adalah proses dilakukannya upaya untuk tegaknya atau berfungsinya norma-norma hukum secara nyata sebagai pedoman perilaku dan dalam lalu lintas atau hubungan-hubungan hukum dalam kehidupan bermasyarakat dan bernegara. Penegakan hukum Islam yang progresif bukan hanya sebatas normatif saja, melainkan juga dilakukan dengan cara yang adil dan jujur. Keadilan dan kejujuran sebagai tujuan hukum Islam ini dilandasi oleh Al-Qur'an dan hadis. Dari sisi ini, Islam melihat keadilan itu bukan hanya sebatas tekstual Al-Qur'an dan hadis saja, namun harus dalam konteks ruang dan waktu sosiologis, seperti yang pernah dilakukan oleh Umar bin Khattab ra. dalam melakukan kebijakan pemerintahannya dalam melakukan dan penegakan hukum mengedepankan hukum Islam progresif.

Hukum Indonesia dalam pendekatan hukum Islam progresif merupakan agama yang universal yang kebenarannya tidak terukur pada ruang dan waktu, sebagaimana ditegaskan dalam dalam firman Allah swt. surah Saba: 28,

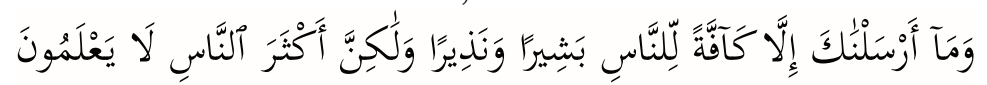

Artinya:

"Dan kami tidak mengutus kamu, melainkan kepada umat manusia seluruhnya sebagai pembawa berita gembira dan sebagai pemberi peringatan, tetapi kebanyakan manusia tiada mengetahui."

Juga ditegaskan dalam firman Allah yang lain dalam surah al-Anbiya: 107,

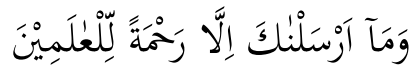

Artinya:

"Dan tiadalah kami mengutus kamu, melainkan untuk (menjadi) rahmat bagi semesta alam." "

Bagi umat Islam, ketentuan normatif ideologis di atas dipahami bahwa Islam sebagai agama yang universal memiliki sifat-sifat asasi, yaitu: 1) kaffah; menyeluruh, lengkap, utuh dan komprehensif; 2) rahmatan lil 'âlamĩn; rahmat bagi seluruh ummat manusia, segala kelompok dan segala bangsa; 3) fitri; alami; sesuai dengan

${ }^{7}$ Batubara, Damri. Hukuman mati bagi pelaku tindak pidana korupsi (studi komparatif hukum pidana di Indonesia dan hukum Islam). Disertasi: IAIN Padangsidimpuan, 2012.

${ }^{8}$ Kementrian Agama RI, Al-Qur'an Dan Terjemahnya

${ }^{9}$ Kementrian Agama RI, Al-Qur'an Dan Terjemahnya 


\section{BUSTANUL FUQAHA: \\ JURNAL BIDANG HUKUM ISLAM \\ Vol. 2 No. 2 (2021): Hal. 181-192 \\ EISSN: 2723-6021 \\ Website: https://journal.stiba.ac.id}

kecenderungan-kecenderungan yang baik, harkat, martabat, kemampuan dan kebutuhan manusia; 4) wasath; wajar, proporsional, tidak berlebih-lebihan.

Selain itu, ajaran Islam juga mempunyai kaidah-kaidah yang bersifat tetap, tidak berubah-ubah seperti yang termuat dalam al-tasyri'i ilahi (nas-nas Al-Qur'an dan Sunah yang qath'iy al-ma'na dan al-wurud) dan juga mempunyai sifat yang dinamis, lentur dan fleksibel sebagaimana termuat dalam al-tasyri' al-wadl'iy. Dengan sifat ini, ajaran Islam mampu merespon dan menampung masalah yang timbul sesuai dengan irama kemajuan, kebutuhan dan perkembangan masyarakat serta kehidupan manusia.

Tujuan hukum pada umumnya adalah untuk menegakkan keadilan berdasarkan kemauan pencipta manusia sehingga terwujud ketertiban dan ketentraman masyarakat. Namun bila tujuan hukum Islam dilihat dari ketetapan hukum yang dibuat oleh Allah swt. dan Nabi Muhammad saw., baik yang termuat di dalam Al-Qur'an maupun hadis, yaitu kemaslahatan hidup manusia baik jasmani maupun rohani individu dan masyarakat.

Kemaslahatan dimaksud dirumuskan oleh Abu Ishak al-Syathibi dan disepakati oleh ahli hukum Islam lainnya seperti yang telah dikutip oleh H. Hamka Haq, yaitu memelihara agama, jiwa, akal, keturunan, dan harta. ${ }^{10}$ Jeje Abdul Rajak mengutip pendapat Imam al-Gazali, yaitu mengemukakan bahwa tujuan umum syariat Islam yang diperuntukkan seluruh makhluk (manusia) itu ada lima hal, yaitu: 1) melindungi agama. 2) melindungi jiwa. 3) melindungi akal. 4) melindungi keturunan. 5) melindungi harta benda $^{11}$. Selanjutnya Imam al-Gazali mengemukakan bahwa setiap sesuatu, perbuatan dan usaha yang diarahkan untuk menjamin terlindunginya kelima hal tersebut merupakan kemaslahatan, sedang menentang, mengabaikan kelima hal itu adalah pengrusakan (mafsadah) dan menolak pengrusakan itu merupakan maslahat ${ }^{12}$.

Menurut K. H. M. Sahal Mahfudh, fungsi dan peranan Agama Islam (nilai-nilai Islam) dalam kehidupan manusia adalah: 1) Sebagai standar penilaian yang berfungsi sebagai landasan yang menuntun untuk menilai sesuatu, bersikap, berfikir dan pandangan selain itu juga berfungsi mengontrol arus perkembangan yang timbul dengan diselaraskan dengan apa yang diajarkan oleh syariah; 2) Memberikan kesadaran teologi bagi manusia untuk berkembang dan maju. Jalan yang ditempuh adalah penyadaran eksistensi manusia dan kehidupan. Selanjutnya akan tercipta kehidupan yang disiplin dan berkembang pesat namun juga bermoral dan dinamis; 3) Motivasi tumbuhnya manusia yang sempurna (insan kamil), dalam arti yang punya potensi keagamaan dan memadai dan disamping itu punya kesadaran secara pasti akan pentingnya aspek non agamis baik secara individual maupun bagi scoup sosial yang lebih luas ${ }^{13}$.

Berdasarkan hal tersebut, cita-cita dan tujuan atau maqasid al-syariah Islam ialah untuk menghantarkan dan membawa sampai finis dalam rangka melenyapkan dan meniadakan serta menolak mafsadat (bahaya) yanag diduga akan menimpa mereka perbuatan korupsi, termasuk perbuatan yang bersifat mafsadat, sebaliknya yang sadar tidak melakukan perbuatan korupsi, akan mendatangkan kemaslahatan (kebaikan) terhadap harta benda dan Kemanusiaan.

\footnotetext{
${ }^{10}$ H. Hamka Haq, Filsafat Ushul Fiqh (Makassar: Yayasan Al-Ahkam, 1998). h. 68

11 Jeje Abdul Rajak, "Penanggulangan Korupsi Dalam Prespektif Hukum Islam" (Suranaya: IAIN Sunan Ampel, 2009), h.7.

${ }_{12}$ Al-Shatibi, Al-Muwafaqot Fi Ushul Al-Fiqh (Bairut: Dar al- Kutub al-Ilmiah, 2002)., h. 3-60

${ }^{13}$ K. H. M. Sahal Mahfudh, Nilai-Nilai Islam Menyongsong Abad XXI (Jember, 1988).h. 34.
} 


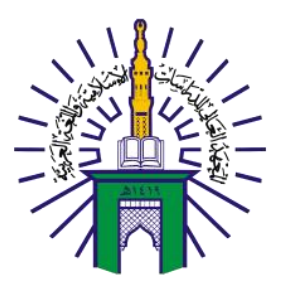

\section{BUSTANUL FUQAHA: \\ JURNAL BIDANG HUKUM ISLAM \\ Vol. 2 No. 2 (2021): Hal. 181-192 \\ EISSN: 2723-6021 \\ Website: https://journal.stiba.ac.id}

\section{BUSTANUL FUQAHA}

Jurnal Bidang Hukum Islam

Lembaran sejarah Islam telah diberikan beberapa langkah terobosan penanggulangan korupsi seperti kebijakan-kebijakan khalifah Umar bin Khattab ra. pada masa pemerintahannya untuk menanggulangi tindak pidana korupsi, antara lain: (1) Memberi gaji yang cukup bagi biaya hidup karyawan dan keluarganya; (2) Dilakukan wajib daftar kekayaan bagi para pegawai, kebijaksanaan seperti itu dikenal dengan "ta'dibul-muwazhaf bil muqasamah-fil-amwal"; (3) Merealisasikan Q.S. al- Hasyr: 7: (4) Melakukan "al-taftisy" (waskat) oleh "shahibul-ummal" kepada bawahannya. Rasulullah saw. melarang seorang pegawai menerima "risywah" (suap) dari rakyat. Beliau menjatuhi hukuman administratif berupa teguran, dalam peristiwa Ibnul Lutabiyah yang diangkat menjadi pegawai zakat dan menerima hadiah dari salah seorang anggota masyarakat wajib zakat. (Al-Bukhari, Muslim, dan Abu Dawud)".

Setiap muslim sebagaimana penjelasan Al-Qur'an dan Sunah memiliki kewajiban yang sama untuk memberantas korupsi, karena korupsi adalah salah satu dari bentuk kemungkaran yang harus diberantas. Allah berfirman dalam Q.S. Ali 'Imran:104,

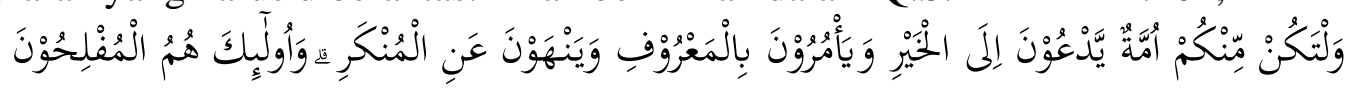

Artinya:

"Hendaklah ada di antaramu kelompok yang selalu mengajak kepada kebajikan dan memerintahkan kepada yang ma'ruf dan mencegah dari kemungkaran. Mereka itulah orang-orang yang akan mencapai kebahagiaan. ${ }^{14}$

Kewajiban untuk "beramar makruf", artinya perintah kepada semua orang Islam baik perseorangan maupun kolektif untuk melakukan sosialisasi dan internalisasi nilainilai Islam ke dalam semua bentuk aktivitas kepada siapa pun, dimana pun dan kapan pun. Di samping itu, juga melakukan upaya pemberdayaan bagi umat manusia agar mereka berkemauan dan berkemampuan untuk berpihak kepada kebenaran, melaksanakan dan memperjuangkannya. Sedangkan kewajiban "bernahimunkar", artinya perintah kepada semua orang Islam baik perseorangan maupun kolektif untuk tidak berpihak kepada "ketidakbenaran", menghindarkan diri dan mencegah dirinya dan orang lain untuk tidak berbuat sesuatu yang tidak dibenarkan oleh agama, baik dalam wilayah ibadah (hubungan vertikal antara manusia dengan Tuhan), maupun dalam wilayah muamalah (hubungan horisontal antarmanusia), termasuk di dalamnya hubungan antara manusia dengan makhluk-makhluk Tuhan (selain manusia). ${ }^{15}$

\section{Hukum Islam Tentang Hukuman bagi Pelaku Tindakan Pidana Korupsi (Koruptor)}

Hukum tindak pidana korupsi di Indonesia, dasar hukumnya adalah UndangUndang Nomor 31 Tahun 1999 dan Undang-Undang Nomor 20 Tahun 2001 tentang Pemberantasan Tindak Pidana Korupsi. Hal ini sesuai dengan keputusan Tap. MPR Nomor XI/MPR/1998 tentang Pemberantasan Tindak Pidana Korupsi yang mulai berlaku sejak tanggal 16 Agustus 1999, dan dimuat dalam Lembaran Negara Republik Indonesia Tahun 1999 Nomor 140.

\footnotetext{
${ }^{14}$ Kementrian Agama RI, Al-Qur'an Dan Terjemahnya

15 Muhsin Hariyanto, "Korupsi Dalam Perspektif Islam" (Universitas Muhammadiyah Yogyakarta, 2004).h. 5
} 


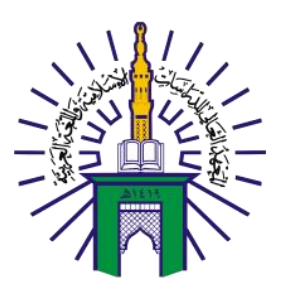

\section{BUSTANUL FUQAHA: \\ JURNAL BIDANG HUKUM ISLAM \\ Vol. 2 No. 2 (2021): Hal. 181-192 \\ EISSN: 2723-6021 \\ Website: https://journal.stiba.ac.id}

Dalam Undang-Undang Nomor 31 Tahun 1999 sebagaimana telah diubah oleh Undang-Undang Nomor 20 Tahun 2001 tentang Pemberantasan Tindak Pidana Korupsi tidak ditemukan rumusan atau definisi apa sebenarnya yang dimaksud dengan tindak pidana korupsi. Namun demikian, mengingat kedua undang-undang ini adalah undangundang yang saat ini berlaku (hukum positif) maka tidak ada salahnya apabila pada bagian ini diuraikan tipologi atau bentuk perbuatan yang dapat dikategorikan sebagai tindak pidana korupsi menurut kedua undang-undang ini. Tidak ada definisi baku dari tindak pidana korupsi. Akan tetapi secara umum, pengertian tindak pidana korupsi adalah suatu perbuatan curang yang merugikan keuangan negara, atau penyelewengan atau penggelapan uang negara untuk kepentingan pribadi dan orang lain ${ }^{16}$.

Marwan Mas mengklarifikasikan setidaknya 7 (tujuh) bentuk dan 30 jenis perbuatan korupsi (diatur dalam 13 pasal UU Korupsi), mulai dari Pasal 2 sampai Pasal 12B UU Korupsi, kecuali Pasal 4 dan Pasal 12 A sebagai berikut ${ }^{17}$ :

1) Kerugian Keuangan/Perekonomian Negara

Melawan hukum dan penyalahgunaan wewenang, kesempatan, atau sarana karena jabatan atau kedudukan yang dapat merugikan keuangan dan perekonomian negara.

2) Suap Menyuap (sogokan atau pelicin)
a) Menyuap pegawai negeri
b) Menyuap hakim.
c) Menyuap advokat.
d) Hakim dan advokat menerima suap

3) Penggelapan dalam Jabatan

a) Pegawai negeri menggelapkan uang negara, atau membiarkan penggelapan.

b) Pegawai negeri memalsukan buku untuk pemeriksaan administrasi.

c) Pegawai negeri merusak bukti (korupsi).

d) Pegawai negeri membiarkan orang lain merusak barang bukti.

e) Pegawai negeri membantu orang lain merusak barang bukti.

4) Pemerasan

5) Perbuatan Curang

a) Pemborong berbuat curang.

b) Pengawas proyek membiarkan perbuatan curang.

c) Rekanan TNI/Polri membiarkan perbuatan curang.

d) Pengawas Rekanan TNI/Polri membiarkan perbuatan curang.

e) Penerima barang TNI/Polri membiarkan perbuatan curang.

f) Pegawai negeri menyerobot tanah negara yang merugikan orang lain.

6) Benturan kepentingan dalam pengadaan

7) Gratifikasi (pemberian hadiah)

Pemberian sanksi merupakan bentuk pertanggungjawaban yang dibebankan kepada seseorang yang telah terbukti melakukan perbuatan pidana, serta orang tersebut telah memenuhi tiga elemen penting agar seseorang itu dapat dimintai pertanggungjawabannya. Pada tindak pidana korupsi sendiri berdasarkan Undang-

\footnotetext{
${ }^{16}$ Aziz Syamsuddin, Tindak Pidana Khusus (Jakarta: Sinar Grafika, 2011). h. 15.

${ }^{17}$ Ade Fajar Rezeki, Skripsi: "Tindakan Pidana Korupsi Menurut UU NO.31 Tahun 1999 jo UU No.20 Tahun 2001 Dan Hokum Islam" (Medan:USU,2017), h. 39
} 


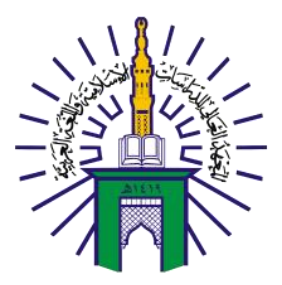

\section{BUSTANUL FUQAHA: \\ JURNAL BIDANG HUKUM ISLAM \\ Vol. 2 No. 2 (2021): Hal. 181-192 \\ EISSN: 2723-6021 \\ Website: https://journal.stiba.ac.id}

Undang Nomor 31 Tahun 1999, Undang-Undang 20 Tahun 2001, sanksi pidana yang dapat diberikan kepada pelaku tindak pidana korupsi adalah sebagai berikut ${ }^{18}$ :

1. Terhadap orang yang melakukan tindak pidana korupsi:
a. Pidana Mati
b. Pidana Penjara
c. Pidana Tambahan

2. Terhadap Tindak Pidana Korupsi yang dilakukan oleh atau atas nama suatu korporasi, hukuman pokok yang relevan adalah hukuman denda, sebagaimana yang diatur dalam Pasal 20 ayat (7) Undang-Undang Tindak Pidana Korupsi yang secara tegas mengatakan bahwa pidana pokok yang dapat dijatuhkan terhadap korporasi hanya berupa pidana denda semata, dengan ketentuan bahwa maksimum pidananya ditambah denga $1 / 3$ (sepertiga)-nya.

\section{Pengaturan Tindak Pidana Korupsi Menurut Hukum Islam}

Secara umum diketahui bahwa segala hal-hal yang dituliskan di dalam Al-Qur'an merupakan pengaturan yang bersifat umum. Oleh karenanya, terkait dasar hukum tindak pidana korupsi menurut hukum Islam, di dalam Al-Quran ada beberapa potongan ayat Al-Quran yang memberikan pandangan terhadap tindak pidana korupsi. Adapun ayatayat yang berkenaan dengan masalah korupsi, yaitu antara lain:

1. Surah Ali Imran: 161,

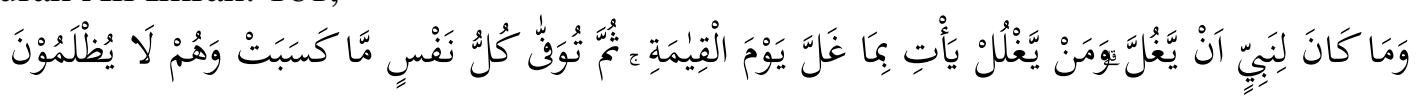

Artinya:

"Dan tidak mungkin seorang nabi berkhianat (dalam urusan harta rampasan perang). Barangsiapa berkhianat, niscaya pada hari Kiamat dia akan datang membawa apa yang dikhianatkanya itu. Kemudian setiap orang akan diberi balasan yang sempurna sesuai dengan apa yang dilakukannya, dan mereka tidak dizalimi. ${ }^{19,}$

2.Surah al-Nisa: 29 ,

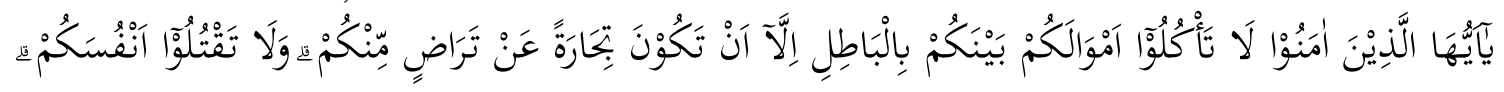

$$
\text { إنَّ اللهُ كَانَ بِكُمْ رَحِيْمًا }
$$

Artinya:

"Hai orang-orang yang beriman, janganlah kamu saling memakan harta sesamamu dengan jalan yang batil, kecuali dengan jalan perniagaan yang berlaku dengan suka sama-suka di antara kamu. dan janganlah kamu membunuh dirimu Sesungguhnya Allah adalah Maha Penyayang kepadamu. ${ }^{20,}$

3. Surah al-Baqarah: 188 ,

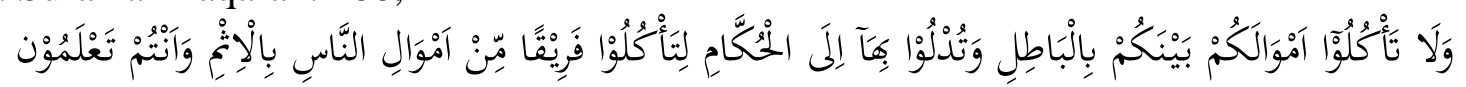

Artinya:

${ }^{18}$ Ade Fajar Rezeki, "Tindakan Pidana Korupsi Menurut UU NO.31 Tahun 1999 Jo UU No.20

Tahun 2001 Dan Hokum Islam” (Medan: Universitas Sumatera Utara, 2017). h. 50

${ }^{19}$ Kementrian Agama RI, Al-Qur'an Dan Terjemahnya

${ }^{20}$ Kementrian Agama RI, Al-Qur'an Dan Terjemahnya 
"Dan janganlah sebahagian kamu memakan harta sebahagian yang lain di antara kamu dengan jalan yang bathil dan (janganlah) kamu membawa (urusan) harta itu kepada hakim, supaya kamu dapat memakan sebahagian daripada harta benda orang lain itu dengan (jalan berbuat) dosa, padahal kamu Mengetahui. ${ }^{21}$,

Dasar hukum tindak pidana korupsi menurut hukum Islam juga dapat dilihat dari beberapa hadis Rasulullah saw. yang berkaitan dengan korupsi yaitu:

Dari Adiy bin Amirah al-Kindi radhiyallahu 'anhu, ia berkata, "Aku pernah mendengar Nabi shallallahu alaihi wa sallam bersabda, 'Barangsiapa di antara kalian yang kami tugaskan untuk suatu pekerjaan (urusan), lalu dia menyembunyikan dari kami sebatang jarum atau lebih dari itu, maka itu adalah ghulul (belenggu, harta korupsi) yang akan dia bawa pada hari kiamat'." Ia berkata, "Ada seorang lelaki hitam dari Anshar berdiri menghadap Nabi shallallahu alaihi wa sallam, seolah-olah aku melihatnya, lalu dia berkata, 'Wahai Rasulullah, copotlah jabatanku yang engkau tugaskan'. Nabi shallallahu alaihi wa sallam bertanya, 'Ada apa gerangan?' Dia menjawab, 'Aku mendengar engkau berkata demikian dan demikian'." Beliau shallallahu alaihi wa sallam pun berkata, "Aku katakan sekarang, (bahwa) barangsiapa di antara kalian yang kami tugaskan untuk suatu pekerjaan (urusan), maka hendaklah dia membawa (seluruh hasilnya), sedikit maupun banyak. Kemudian, apa yang diberikan kepadanya, maka dia (boleh) mengambilnya. Sedangkan apa yang dilarang, maka tidak boleh." ${ }^{22}$

Korupsi dalam Islam digolongkan sebagai suatu perbuatan yang tercela dan sangat merugikan orang lain maupun bangsa Indonesia serta pelakunya termasuk sebagai orangorang yang munafik, dzalim, kafir, dan merupakan dosa yang besar karena mereka telah memakan atau mengambil sesuatu yang bukan haknya atau bukan miliknya dan ancaman hukumannya adalah neraka jahanam.

Beberapa jenis tindak pidana (jarimah) dalam fiqh jinayah dari unsur-unsur dan definisi yang mendekati pengertian korupsi di masa sekarang adalah:

a) ghulul (penggelapan);

b) risywah (penyuapan);

c) ghasab (mengambil paksa hak/harta orang lain);

d) khianat;

e) sariqah (pencurian);

f) hirabah (perampokan);

g) al-maks (pungutan liar), al-ikhtilas (pencopetan), dan al-ihtihab (perampasan); ${ }^{23}$

Hukum Pidana Islam mengenai tindak pidana korupsi terkait sanksi pidana, dikenal ada empat sanksi yang dapat diberikan yaitu takzir, sanksi moral, sanksi sosial dan sanksi akhirat. Takzir adalah sebuah sanksi hukum yang diberlakukan kepada seorang pelaku jarimah atau tindak pidana yang melakukan pelanggaran-pelanggaran, baik berkaitan dengan hak Allah maupun hak manusia dan pelanggaran-pelanggaran dimaksud tidak masuk dalam kategori hukum hudud dan kafarat.

Sanksi moral, sanksi sosial dan sanksi akhirat tidak bisa ditemukan dalam berbagai rumusan pasal UU No. 31 Tahun 1999 tentang Pemberantasan Tindak Pidana

\footnotetext{
${ }^{21}$ Kementrian Agama RI, Al-Qur'an Dan Terjemahnya

${ }^{22}$ Ade Fajar Rezeki, Skripsi: "Tindakan Pidana Korupsi Menurut UU NO.31 Tahun 1999 jo UU No.20 Tahun 2001 Dan Hokum Islam" (Medan:USU,2017), h. 60

${ }^{23}$ Nurul Irfan, Korupsi Dalam Hukum Pidana Islam (Jakarta: Amzah, 2011). h.78.
} 
Korupsi. Menghukum sesorang dalam korupsi dengan cara yang manusiawi, dan harus melihat aspek sosiologis mereka terdahulu, mengapa ada sebuah korupsi yang dilakukan oleh para pejabat negara atau pegawai bahkan oleh rakyat itu sendiri, maka yang perlu digarisbawahi adalah sudahkah memahami sebuah kesadaran hukum dan memiliki bekal ketauhidan dan Islam yang kuat, kalau tanpa melihat itu maka tanggungjawab sebagai sistem negara yang didalamnya bukan hanya sebatas hukum normatif, tetapi ada yang dikatakan pemabangunan yang berangkat dari ketidakteraturan bangsa seperti sekarang yang dirasakan Indonesia yang mayoritas Islam, maka sesorang hakim dan penegak hukum lainnya dalam melakukan penegakan harus melihat faktor sosiologis masyarakat, sebab ini ada kesalahan besar yang dilakukan sistem Indonesia dalam menjalankan roda ketatanegaraan. Diyakini ini bias dari runtuhnya sebuah konstitusi yang tidak berdasarkan grand father UUD 1945 dan Pancasila, tetapi lebih menggunakan pendekatan budaya hukum kapitalisme, bukan menggunakan pendekatan hukum Islam progresif.

Dalam konteks Indonesia sekarang ini, belum terlihat ada upaya untuk membenahi hal ini yaitu dengan usaha yang benar-benar terlahir dari mukjizat Al-Qur'an dan hadis serta jiwa Pancasila, padahal ketiganya terbukti sangat efektif, apabila diterapkan dan jadikan sebagai jiwa dan semangat penegakan hukum terhadap budaya kejahatan korupsi. Fakta yang ada, penyelesaian ketidakteraturan negara dan bangsa justeru keluar dari tiga aspek di atas. Oleh karenanya, untuk menegakan sebuah keadilan yang berperspektif skala makro dan mikro hukum, harus mengedepankan keseimbangan kondisi sosiologis masyarakat sebagai subjek hukum, sehingga hukum tidak berdampak seperti monster yang menakutkan ${ }^{24}$. Hukum seharusnya dapat menjadi pemicu dalam mewujudkan harmonisasi dalam masyarakat Indonesia. Untuk membenahi hukumnya, Indonesia harus membenahinya secara normatif yuridis, agar subjek hukum kejahatan korupsi yang sudah menjalar dalam tubuh negara dan bangsa bisa ditegakkan, selain melakukan penyadaran dan edukasi hukum.

Abdul Qadir Audah memberi definisi jarimah, "Sesungguhnya (jarimah) itu adalah segala larangan yang dilarang oleh Allah dan diancam dengan pidana, baik berupa had maupun takzir. Sedang yang dimaksudkan dengan larangan (mahzhurat) adalah melakukan perbuatan yang dilarang atau meninggalkan (tidak melakukan) perbuatan yang diperlukan.” Audah menjelaskan bahwa jarimah itu dapat dibagi menjadi:

1) Jarimah al-Hudud adalah tindak pidana yang kadar pidananya telah ditentukan dan ditetapkan oleh Allah. Tindak pidana ini meliputi: perbuatan zina, menuduh orang lain melakukan zina, mencuri, minumminuman keras, perampokan dan pembegalan, riddah (keluar dari Islam), pemberontakan (bughah) untuk menggulingkan kekuasaan yang sah atau membuat huruhara;

2) Jarimah al-Qishash adalah tindak pidana yang diancam dengan sanksi pidana berupa qishash atau diyat. Kadar qishash dan diyat juga telah ditetapkan oleh Allah. Tindak pidana qishash ini meliputi: pembunuhan dengan sengaja, pembunuhan menyerupai sengaja, pembunuhan karena kealpaan, penganiayaan dengan sengaja, penganiayaan karena kealpaan ${ }^{25}$.

${ }^{24}$ Abdul Qadir Audah, At-Tasyri'ul Jinail Islami Muqoronan Bi Al-Qanunil Wadl'iy, Juz I (Cairo: Matbaah Dar al-Nasyri al-Tsaqofah Iskandariyah, 1949).h. 66

${ }^{25}$ Abdul Qadir Audah, At-Tasyri'ul Jinail Islami Muqoronan bi al-Qanunil Wadl'iy, Juz I (Kairo: Matbaah Dar al-Nasyri al-Tsaqofah Iskandariyah, 1949), h. 67 
Ada kaidah-kaidah umum dalam asas-asas hukum pidana Islam, antara lain: 1) Hukuman orang kecil adalah kecil, dan hukuman orang besar adalah besar. Artinya, hukuman terhadap kejahatan besar, harus besar, sedang kejahatan ringan, harus ringan pula; 2) Manakala kemaslahatan publik menuntut untuk diperberat, maka hukuman diperberat; dan manakala kemaslahatan publik menuntut diperingan, maka hukuman diperingan ${ }^{26}$.

Hukum pidana Islam merupakan terjemahan dari kata fiqh jinayah. Fiqh jinayah adalah segala ketentuan hukum mengenai tindak pidana atau perbuatan kriminal yang dilakukan oleh orang-orang mukalaf sebagai hasil dari pemahaman atas dalil-dalil hukum yang terperinci dari Al-Qur'an dan hadis ${ }^{27}$. Hukum pidana Islam merupakan syariat Allah yang mengandung kemaslahatan bagi kehidupan manusia baik di dunia maupun di akhirat. syari'at Islam dimaksud secara materiil mengandung kewajiban asasi bagi setiap manusia untuk melaksankannya. Konsep kewajiban asasi syari'at yaitu menempatkan Allah sebagai pemegang segala hak, baik yang ada pada diri sendiri maupun yang ada pada orang lain. Setiap orang hanya pelaksana, yang berkewajiban memenuhi perintah Allah.

Perintah Allah dimaksud, harus ditunaikan untuk kemaslahatan dirinya dan orang lain. Sehingga di dalam Islam, ada ketentuan kewajiban untuk melaporkan suatu tindak kejahatan, yaitu apa yang dikenal dalam hukum pidana modern dengan mekanisme "crime watch." Hal apabila diterapkan dalam tindak pidana korupsi akan lebih bermanfaat bagi kepentingan umat, sehingga dapat melakukan partisipasi bangsa dan seluruh rakyat Indonesia untuk bersama-sama dengan semangat memberantas kejahatan pidana korupsi di kalangan pejabat atau kejahatan oleh kerah putih dan lebih umum lagi di kalangan segenap lapisan masyarakat Indonesia, maka dari itu secara otomatis harapannya akan melahirkan tujuan syariat (maqasid al-syariat), berbangsa dan bernegara yang dilandasi keadilan dan kejujuran dalam pandangan Al-Qur'an dan Islam secara kaffah.

Selain itu, ada dua faktor yang membuat proses kesadaran dan penegakan hukum Islam progresif terhadap kejahatan tindak pidana korupsi di Indonesia, yaitu faktor internal dan faktor eksternal. Pertama, faktor internal, yaitu faktor-faktor yang terdapat dalam diri seseorang yang disebabkan oleh: 1) kekuatan dan internalisasi iman/tauhid; 2) Implementasinya akhlak/moral (mutmainnah, jujur, amanah, adil); 3) memiliki ilmu yang mengantarkan kebenaran dan tingkat disiplin tinggi; 4) memiliki jiwa dan pikiran yang Qur'ani sebagai dasar kekuatan akidah dan ketauhidan yang menyadarkan pada 3 aspek, yaitu aspek berlindung segalanya pada pedoman Allah swt., membesarkan kekuasaan Allah swt., dan semuanya diniati karena menyembah Allah swt. bukan selain-Nya. Kedua, faktor eksternal adalah faktor-faktor yang terdapat di luar diri seseorang yang meliputi antara lain: 1) adanya atau memiliki jiwa dan skill kepemimpinan dalam posisi simpul yang mampu memberikan cahaya Al-Qur'an dan Sunnah Rasulullah saw., dan mempengaruhi tingkah laku yang menunjukkan tidak melakukan perbuatan tindak pidana korupsi; 2) memiliki jiwa wara' serta menerima dengan ikhlas gaji atau pendapatan pegawai negeri walaupun kebutuhan yang makin hari makin meningkat, sebab yang dilakukannya sebagai pengabdian kepada negara dan rakyat; 3) membentuk siklus

${ }^{26}$ Jeje Abdul Rajak, "Penanggulangan Korupsi,", h. 12.

27 Dede Rosyada, Hukum Islam Dan Pranata Sosial (Jakarta: Lembaga Study Islam dan Kemasyarakatan, 1992). h. 86. 
kebudayaan atau kultur Indonesia yang bertaqwa dan berakhlak mulia sebagai sumber tidak melakukan korupsi; 4) memiliki skill dan praktek manajemen yang baik dan kontrol yang efektif dan efesien serta professional dan proforsional akan tidak memberikan peluang dan kesempatan bagi orang untuk melakukan perbuatan dan tindak pidana korupsi; 5) kesejahteraan dalam menerima kompensasi dari pihak perusahaan dan negara; 6) taraf sinkronisasi regulasi atau peraturan perundangan dengan yang seimbang dan memiliki kepastian hukum, kemanfaatan dan keadilan hukum yang terlahir dari nilai-nilai Al-Qur'an dan hadis Rasulullah saw. (Sunnah), sehingga menciptakan mental yang tinggi dan memanusiakan manusia sebagai khalifah Allah swt., dalam rangka untuk penegak hukum Indonesia dalam perspektif hukum Islam dan progresif; 7) mengintegrasikan atau pembagian fasilitas dengan merata dan adil serta sikap yang lebih mementingkan kepentingan tanggungjawab diri untuk kepentingan umum dari pada kepentingan hak atas fasilitas diri dalam menjalankannya; dan 8) masyarakat dan lingkungan keluarga yang mendukung dan memotivasi untuk berbuat positif atau menjalankan tugas maksimal dengan tidak melakukan korupsi.

Dengan perspektif hukum Islam progresif dalam integrasi hukum nasional (positif) inilah akan memulai melakukan penegakan hukum terhadap kejahatan korupsi, dengan modernisasi pemahaman hukum Islam yang semakin progresif, di mana dapat memberikan penyadaran terhadap pejabat, masyarakat dan siapa pun, karena dengan melakukan penegakan hukum dalam perspektif hukum Islam yang progresif yang mampu menginjeksi nilainilainya pada hukum positif dan secara langsung dapat merubah karakter kepribadian jiwa dan pikiran personal muslim yang mayoritas Indonesia beragama muslim, maka akan melahirkan kepastian hukum, kemanfaatan dan keadilan pada hukum Indonesia yang benar-benar progresif sekali yang bersumber dari haqqumirrabbik (Al-Qur' an dan hadis).

Tegasnya, penyebab tidak terjadinya korupsi terdiri dari tiga faktor, yaitu: 1) faktor mental yang tangguh atau istikamah menjalankan sidiq (kejujuran), amanah (kepercayaan), tablig (menyampaikan) dan fathanah (kecerdasan spiritual, intelegent, dan emosional); 2) faktor kondisi sosial ekonomi yang menerima dengan ikhlas dan ridha; dan 3) faktor sistem tata-aturan. Faktor mental artinya moral yang memberikan mental yang berjiwa husnu zhan (berbaik sangka), tidak diperbudak nafsu amarah, kerakusan dan iri hati, tamak, gila harta, tidak gila jabatan, jujur, tidak serakah, qanaah, menjalankan wewenang dengan amanah, justeru memberikan hartanya untuk menopang, tidak menyalahgunakan wewenanag serta tidak memperkaya diri sendiri; Faktor kondisi sosial ekonomi, yaitu: kondisi sosial ekonomi sehat, sejahtera secar menerima dengan lapang dada, memiliki aktifitas postif, kekayaan diberikan sebagaian sebagai zakat mal dan profesi kepada kaum minoritas, dan dan berusaha dengan usaha pemerataan hasil pembangunan; dan faktor sistem tata-aturan: seperti pengumpulan dana yang dilindungi oleh undang-undang, sistem manajemen yang terbuka, sistem pengawasan yang efektif, dan lain sebagainya.

\section{KESIMPULAN}

Korupsi adalah perbuatan yang mengandung banyak definisi yang sesuai dengan pemahaman dari Al-Qur'an, hadis dan juga hukum Islam. Korupsi di Indonesia dalam perspektif Hukum Pidana Islam adalah usaha memperkaya diri sendiri atau orang lain 
dengan jalan melanggar hukum yang bertentangan dengan prinsip keadilan (al-'adalah), akuntabilitas (al-amanah), dan tanggung jawab dalam suatu jabatan.

Bentuk-bentuk pelanggaran hukum korupsi di Indonesia dalam perspektif hukum Islam adalah bisa berupa ghulul (pengkhianatan), al-ghasy (penipuan), dan risywah (suap), al-hirabah (perampasan), dan al-ghasab (penggunaan hak orang lain tanpa izin). Adapun unsur-unsur tindak pidana korupsi dalam perspektif Hukum Pidana Islam adalah adanya nas yang melarangnya, kemudian telah melakukan perbuatan yang telah menyalahi nas-nas, misalnya berbuat khiyanah/ghulul, al-ghasy (penipuan), risywah (suap), al-hirabah (perampasan), al-ghasab (penggunaan hak orang lain tanpa izin), dan yang terakhir pelakunya adalah orang sudah dapat dibebankan hukum. Hukuman bagi pelaku tindak pidana korupsi dalam Hukum Pidana Islam yang dapat diberikan yaitu takzir, sanksi moral, sanksi sosial dan sanksi akhirat.

\section{DAFTAR PUSTAKA}

Al-Shatibi. Al-Muwafaqot Fi Ushul Al-Fiqh. (Bairut: Dar al- Kutub al-Ilmiah, 2002).

Audah, Abdul Qadir. At-Tasyri'ul Jinail Islami Muqoronan Bi Al-Qanunil Wadl'iy, Juz I. (Cairo: Matbaah Dar al-Nasyri al-Tsaqofah Iskandariyah, 1949).

Batubara, Damri. Hukuman mati bagi pelaku tindak pidana korupsi (studi komparatif hukum pidana di Indonesia dan hukum Islam). Disertasi: IAIN Padangsidimpuan, 2012.

Echols, John M, and Hassan Shadily. Kamus Inggris Indonesia. (Jakarta: Gramedia Pustaka Utama, 2003).

Haq, H. Hamka. Filsafat Ushul Fiqh. (Makassar: Yayasan Al-Ahkam, 1998).

Hariyanto, Muhsin. "Korupsi Dalam Perspektif Islam." (Yogyakarta: Universitas Muhammadiyah, 2004).

Irfan, Nurul. Korupsi Dalam Hukum Pidana Islam. (Jakarta: Amzah, 2011).

Jeremy, Pope. Strategi Memberantas Korupsi : Elemen Sistem Integritas Nasional (Alih Bahasa Masri Maris). (Jakarta: Transparency Internasional Indonesia, 2008).

Kementrian Agama RI. Al-Qur'an Dan Terjemahnya.

Mahfudh, K. H. M. Sahal. Nilai-Nilai Islam Menyongsong Abad XXI. (Jember, 1988).

Munajat, Makhrus. Dekonstruksi Hukum Pidana Islam. (Yogyakarta: Logung Pustaka, 2004).

Rajak, Jeje Abdul. "Penanggulangan Korupsi Dalam Prespektif Hukum Islam." (IAIN Sunan Ampel, 2009).

Rezeki, Ade Fajar. "Tindakan Pidana Korupsi Menurut UU NO.31 Tahun 1999 Jo UU No.20 Tahun 2001 Dan Hokum Islam." (Medan: Universitas Sumatera Utara, 2017).

Rinaldi, Taufik. Memerangi Korupsi Di Indonesia Yang Terdesentralisasi : Studi Kasus Penanganan Korupsi Pemerintah Daerah. (Jakarta: Justice for the poor project, Bank Dunia, 2007).

Rosyada, Dede. Hukum Islam Dan Pranata Sosial. (Jakarta: Lembaga Study Islam dan Kemasyarakatan, 1992).

Soejono. Kejahatan Dan Penegakan Hukum Di Indonesia. (Jakarta: Rineka Cipta, 1996). Syamsuddin, Aziz. Tindak Pidana Khusus. (Jakarta: Sinar Grafika, 2011). 